\title{
The Psychological Motives Of Safe Motherhood Practices: A Case Of Married Females In Gujrat
}

\author{
Ummel Baneen \\ Department of Population Sciences \\ University of Gujrat \\ Fauzia Maqsood \\ Faculty of Social Sciences \\ University of Gujrat \\ Sidra Maqsood \\ Government College University
}

\begin{abstract}
Psychological motives are the important trajectories to increase the awareness about safe motherhood among married females. The current study aimed at examining the relationship between psychological motives of awareness about safe motherhood among married females living in Gujrat. The females who were married, currently living with their husbands, were in reproductive age and enlisted by a lady health worker of the community were the target population of study. The sample of 301 married females was selected through simple random sampling. Interview schedule was used to collect the information from married females. For the analysis of the data Pearson's correlation matrix and simple linear regression was used. Data was analyzed by using computer software SPSS. The results of the study showed that psychological motives that are self-esteem and health locus of control had positive and significant relationship with awareness about safe motherhood among the married females. It can be concluded that females who had favorable level of self-esteem and health locus of control were more aware about safe motherhood practices. The study suggested that the females of more vulnerable group must also be targeted along with their partners. Enhanced psychological services must also be available for the couples.
\end{abstract}

Keywords: Psychological, Motives, Safe Motherhood, Practices, Married Females.

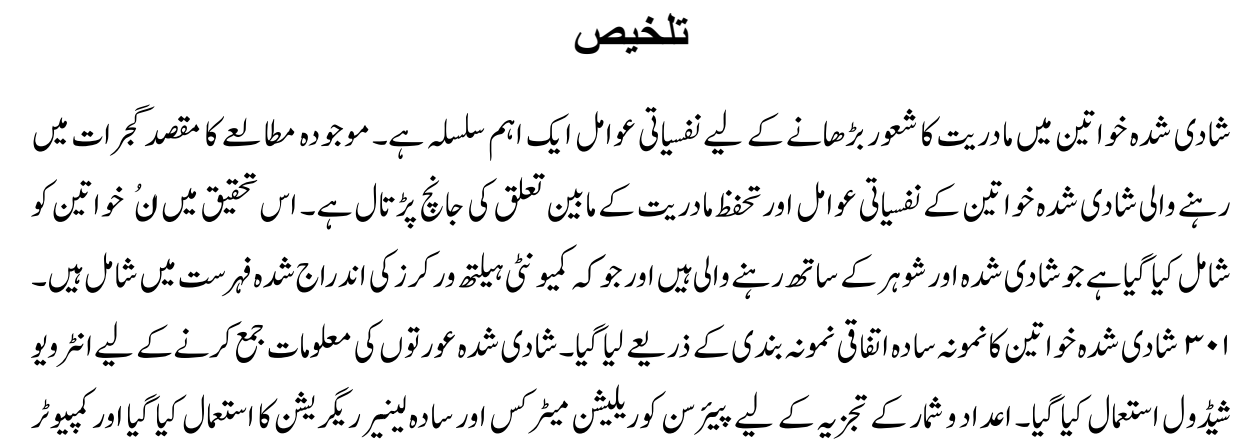




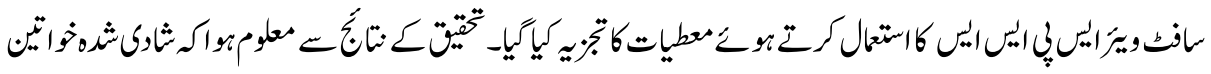

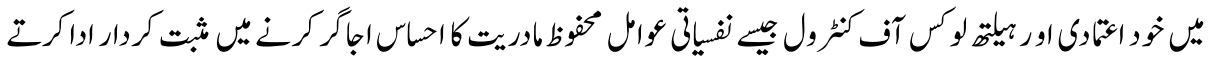

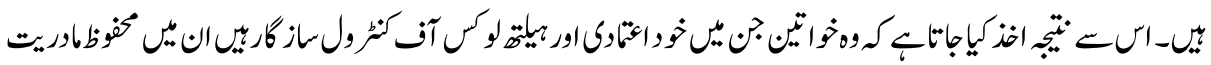

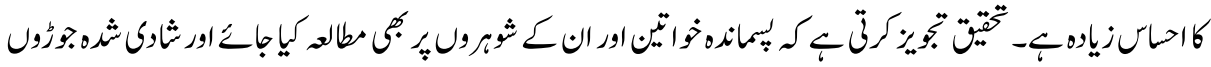

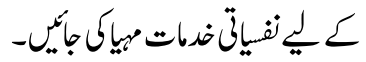

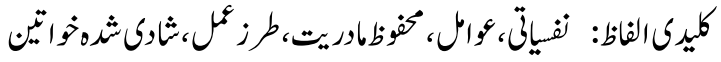

\section{Introduction}

Reproductive health is a very important part of overall health of the individuals. Presence of reproductive health related knowledge brings females in position that enable them to make informed choices about their reproductive health.

Around the globe almost 550,000 maternal deaths occur each year, out of which $90 \%$ happen in developing countries. Usually, the chances of maternal deaths increase because females do not realize that they are suffering from any medical problems or due to the delay in making decision to seek care, or due to less accessibility to the health care centers, which affect their chances to survive in obstetric emergency (Garg, Chhabra and Zothanzami, 2006).

The acquisition of the basic reproductive health related knowledge is important to understand human's reproduction processes, sexually transmitted infections, frequency of contraceptives usageand further information related to human health and procreation (Ugoji, 2004).

Many developing countries are currently having higher maternal mortality rate. Every year a large proportion of the women die due to the complications in the process of child birth. Many of those maternal mortalities are caused by the lack of adequate knowledge about the reproductive health. The figures of maternal mortality are even not less alarming in Pakistan. Estimates depicts that almost 28 thousand maternal mortalities occur each year. Coupled with that fertility rate is also high with low CPR (34\%) in Pakistan (Demographic and Health Survey of Pakistan, 2002).

Awareness about safe motherhood is one of the core pillars of reproductive health awareness among the females. Safe motherhood is conceptualized as the condition in which woman is in the physiological processes of pregnancy and child birth does not suffer any complication or lose her and her baby's life (Action Health, 1999). Safe 
motherhood initiatives also aim at improving the reproductive health status of females. It aims to save the life of a women and improving the health of millions (Jatua, 2000) because these are the serious efforts put on by the mother herself, her immediate and extended family and community and all the level of health care system in order to guarantee her safety during pregnancy, delivery and in the post-partum period as well (Partnership for transforming health care system- PATHS, 2005).

Surat (2002) discussed that safe motherhood is achieved through improved personal hygiene and nutrition of the mother and ensured via effective utilization of the health care services. Literature on reproductive health shows that at the individual level various psychological motives predict the awareness about safe motherhood among females.

In developing countries females of both rural and urban zones are facing pregnancy related complications which are the consequences of poor attitude towards the safe motherhood practices. These females have lack of awareness about the safe motherhood initiatives (John-Nwosu, 2011).

The psychological construct that is health locus of control showed the relationship with health of the individuals. In a study Victor and Haruna (2012) discussed that awareness about transmission and prevention about HIV/AIDS is considered as an important factor for its prevention. As it is also discussed by Lee \& Mancini, (1981) that tendency of using contraceptives is more among those females who have high internal locus of control.

The strong health locus of control among the females helps them to avoid the risky health behavior, to stay safe during pregnancy and to save the life of their infant as well. Similarly, self-esteem is also a predictor of awareness about safe motherhood practices. Self-esteem depicts the overall emotional evaluation of individual's own worth. It is the evaluation of a person about her/his self and attitude towards own self. Self-esteem comprehends the beliefs and emotions (Hewitt, 2009).The females in the developing countries have lack of skilled health services, lack of communication on sensitive matters, and religious and cultural taboos related to their reproductive health (Shirpak, Chinichian, Maticka-Tyndale, Ardebili, Pourreza \& Ramenzankhani, 2008). These factors can influence the decision of a woman to take informed choice abbot her health. The current study aimed at investigating the relationship of psychological motives and the awareness about safe motherhood practices among married females in Gujrat city.

\section{Objectives of the Study}

- To find out the socio-demographic characteristics of the respondents

- To analyze the psychological motives among respondents

- To investigate the awareness about safe motherhood among respondents 
214 The Psychological Motives of Safe Motherhood Practices: A Case of Married Females in Gujrat

- To determine the relationship between psychological motives and awareness about safe motherhood among respondents

\section{Literature Review}

Ravi \& Kulasekaran (2014) aimed at investigating knowledge, opinions and misapprehensions regarding reproductive tract infections (RTIs), sexually transmitted infections (STIs) and HIV/AIDS among young married females. Results of the study revealed that percentage of women who had knowledge about RTIs and STIs was just $28.4 \%$ and $37.9 \%$ respectively. Misconception that RTIs are communicable disease was prevalent among $44.4 \%$ of those young married females. It was depicted in the results of the study that $90.6 \%$ of females had knowledge about HIV/AIDS. Females who responded that HIV/AIDS could be transmitted by sharing the common toilet were $8.8 \%$ and prevalence of misconceptions that bitten by mosquitoes, fleas or bedbugs causes HIV/AIDS transmission was $8 \%$. The females who had high standard of living index were more acquainted of HIV/AIDS (77.4\%) as compared to those who had low standard of living (52.1\%). Lack of awareness about sexual health issues and other communicable diseases was among major public health challenges in rural areas. The study concluded that the major factors contributed towards less awareness about sexual health issues among females living in rural areas were meager standard of health and low level of education. It recommended that the policy makers must introduce community based intervention programs to enhance the awareness among females of rural areas.

Victor and Haruna (2012) conducted a study to investigate the relationship between health locus of control and sexual risk behavior. He investigated this relationship of health Locus of Control to know the perceived control of individuals on their personal health. The researchers revealed that the individuals who had high health locus of control were more likely to use Brief HIV Screener. The study has proven the relationship between health locus of control and sexual risk behavior as statistically significant.

Mondal, Rahman, Rahman \& Akter (2012) aimed to assess the level of awareness regarding HIV/AIDs and to find out the factors affecting knowledge and awareness about control and prevention of HIV/AIDs among ever married females in Bangladesh. They found that the vulnerability towards sexually transmitted diseases (STDs), HIV/AIDS infection and unplanned pregnancies was more among ever married women. The vicariate and multivariate analyses of the study showed that education level of education of respondent, her husband's education and occupation, age at marriage, frequency of watching TV, electricity in household, marital status and residence had significant effect on HIV/AIDs awareness. It was suggested in the study that marriage in the older ages ( $>18$ years), education and mass media campaigns lead to increase knowledge and awareness about HIV/AIDs and STDs among ever married females. 
John-Nwosu (2011) conducted a cross sectional study in Nigeria. Attitude of pregnant women towards the safe motherhood initiatives was investigated. The data was collected by using a questionnaire from 232 pregnant women who were registered in all the fifteen health facilities in Orlu urban. The results of study showed that pregnant women had positive attitude towards safe motherhood initiatives. The study recommended that women of reproductive age be provided with the information about safe motherhood initiatives.

Moshki, Tavakolizadeh \& Bahri (2010) conducted a study to investigate relationship between health control beliefs and life style in pregnancy period. Sample of the study was 115 pregnant females that were referred to therapeutic health centers of Gonabad, Iran. The sample was selected through simple random sampling. The results of the study showed that mean age and pregnancy age of the sample was $20 \pm .27$ years and $23 \pm .6$ weeks respectively. Significant relationship between internal belief of health control and nutrition and life safety during pregnancy period was found in the study. It was concluded that proper teaching methods for pregnant women can support the health belief control among them.

Khan, Zafar, Ali \& Ahmed (2009) investigated the influence of socio-economic, cultural and demographic factors on the reproductive health of women. In this study the socioeconomic factors were the education level and the type of occupation of both husband and wife, family income and structure of the family in which they live. The demographic factors in the study were current age of the couple, size of family, sex preference and marriage patterns. Whereas the cultural factors were investigated through the indicators such as gender roles, participation of females in the household decision making, communication patterns of couples about contraceptives, religious believes, physical and normative cost of contraceptive use, availability and accessibility of reproductive health care services, patterns of utilization of health facilities, attitude towards health facilities and interaction patterns with health care providers. It was concluded in the study that socio-economic factors significantly influence choices of family size about the contraceptive use. The division of gender roles, spousal communication on contraceptive use and participation of females in decision making process was also significantly affecting the reproductive health status. Physical and normative cost of contraceptives was strongly predicting the contraceptive use. Favorable interaction patterns with health care providers had positive relation with utilization of health care services. Utilization of the healthcare services ultimately improves the reproductive health status of the females. 
All the socio-economic, cultural and demographic factors explained in above study increase the self-esteem and strengthen the control of a woman on her health which ultimately lead towards making informed choices about her own health during pregnancy, birth and post-partum period.

Mustafa, Afreen \& Hashmi (2008) conducted a study to investigate the knowledge, attitude and practice regarding family planning methods. Study revealed that most of the women had knowledge about family planning methods. It was also revealed that the women were obtaining this information via media. Most of the respondents were using contraceptives. It was also found in the study that husbands of the respondents had positive attitude towards the use of contraceptives. The researcher suggested that couples can be motivated to use contraceptives through media and health personnel.

The difference regarding awareness about the sexual health also exists across the urban and rural dwellers. Gani, et al. (2011) focused on socio-economic and urban-rural differences in knowledge of STIs and HIV/AIDS of Bangladeshi adolescents. Overall, the STI knowledge was poor (4.5\%), however urban residents had twice the STI knowledge as compared to rural inhabitants. On the other hand, knowledge about HIV/AIDS was relatively high (68\%) and urban area's respondents were also outperforming the rural residents level of knowledge. The onset of STDs/RTIs brings more serious consequences for women that may lead to maternal death (Kambo, 1997). The presence of these diseases increases the risk of contracting and transmission of HIV (Wasserheit, 1992). Somewhat similar findings were drawn in the study conducted by Islam, et al. (2011). The study concluded that more attention must be given to uneducated rural inhabitant women's health care needs.

Daly et al. (1993) and Jatau (2000) discussed the importance of safe motherhood. They conversed that health risks faced by mothers in childbearing ages especially in the teenage mothers are very serious for both mother and child. Among the health risks preeclamptic toxaemia, anaemia, malnutrition, cephalopelvic disproportion, obstetric fistulae, obstructed labour, low birth weight and peri-natal mortality are included. It was also indicated in their studies that these risks are preventable through effective safe motherhood programs and $\mathrm{MCH}$ clinics.

Norman et al (1998) discussed the relationship between internal locus of control and engagement in health promoting activities and behaviors. The results of the study predicted that the individuals who had strong internal locus of control were more likely to engage in health promoting activities and behavior as compared to the external locus of 
control. Individuals who engaged in more health behaviors were more likely to score higher on the internal dimension and lower on the external dimension.

Health locus of control, specifically internal locus of control are affected by the education level of the individuals as discussed by Jejeebhoy (1995) that education plays a significant role in dealing with women's lives like, trends of births and marriages and rely less on traditional beliefs. This infers that women have own beliefs to convene their behavior.

Health of mother and child are also affected by the involvement of men. Husbands perform a significant role in determining maternal health. Punam \& Bhawana (2016) conducted a study in Nepal to assess male's participation in safe motherhood and mentioned that influence of husbands on maternal health is often not given importance. Through conducting a descriptive cross sectional research they found that all of the participants had low knowledge about safe motherhood and therefore had less participation. However, the results also depicted a significant correlation of ethnicity, level of education, type of occupation, level of income with knowledge and practices about safe motherhood practices. The participants who were Brahmin and Chettri's, had graduation and above education level, had government job and had high income were having more knowledge and tilt towards safe motherhood practices.

\section{Methodology}

Quantitative technique was used to investigate the psychological motives of awareness about safe motherhood among married females in Gujrat. Survey method was used as a technique of data collection. Instrument of the data collection for the present study was a well-structured questionnaire and interview schedule was used to collect data.

Unit of analysis of the study was the married females of reproductive age (15-49) that were being covered by lady health workers (LHWs). 301 married females were selected through simple random sampling technique. Sample size was drawn by using Taro Yamane formula.

\section{Results and Discussion}

\section{Socio-demographic Characteristics of the Respondents}

The following tables depict descriptive analysis of the socio-demographic characteristics of the married females. The results of present study show the percent distribution of 
218 The Psychological Motives of Safe Motherhood Practices: A Case of Married Females in Gujrat

females' ages, education, age at marriage, family monthly income, Family size and family type are also shown in the tables.

Table: 1

Age of the respondents

\begin{tabular}{|l|c|c|}
\hline Categories & Frequency (f) & Percent\% \\
\hline $15-19$ & 3 & 1.0 \\
\hline $20-24$ & 24 & 8.0 \\
\hline $25-29$ & 73 & 24.3 \\
\hline $30-34$ & 99 & 32.9 \\
\hline $35-39$ & 68 & 22.6 \\
\hline $40-44$ & 29 & 9.6 \\
\hline $45-49$ & 5 & 1.7 \\
\hline Total & $\mathbf{3 0 1}$ & $\mathbf{1 0 0 . 0}$ \\
\hline
\end{tabular}

Table: 2

Education of respondents

\begin{tabular}{|l|c|c|}
\hline Categories & Frequency (f) & Percent\% \\
\hline $0-5$ & 59 & 19.6 \\
\hline $6-10$ & 120 & 39.9 \\
\hline $11-16$ & 122 & 40.5 \\
\hline Total & $\mathbf{3 0 1}$ & $\mathbf{1 0 0 . 0}$ \\
\hline
\end{tabular}

Table: 3

Respondents' age at marriage

\begin{tabular}{|l|c|c|}
\hline Categories & Frequency & Percent \\
\hline $15-20$ & 132 & 43.9 \\
\hline $21-26$ & 139 & 46.2 \\
\hline $27-31$ & 30 & 10.0 \\
\hline Total & $\mathbf{3 0 1}$ & $\mathbf{1 0 0 . 0}$ \\
\hline
\end{tabular}

Table: 4

Family monthly income (Rs.)

\begin{tabular}{|l|c|c|}
\hline Categories & Frequency & Percent \\
\hline Up to 10000 & 25 & 8.3 \\
\hline $10001-20000$ & 69 & 22.9 \\
\hline $20001-30000$ & 80 & 26.6 \\
\hline $30001-40000$ & 56 & 18.6 \\
\hline $40001 \&$ above & 59 & 19.6 \\
\hline Don't know & 12 & 4.0 \\
\hline Total & $\mathbf{3 0 1}$ & $\mathbf{1 0 0 . 0}$ \\
\hline
\end{tabular}


Table: 5

Respondents' family size

\begin{tabular}{|l|c|c|}
\hline Categories & Frequency & Percent \\
\hline $1-3$ & 28 & 9.3 \\
\hline $4-6$ & 152 & 50.5 \\
\hline $7-9$ & 79 & 26.2 \\
\hline $10-12$ & 42 & 14.0 \\
\hline Total & $\mathbf{3 0 1}$ & $\mathbf{1 0 0 . 0}$ \\
\hline
\end{tabular}

Table: 6

Respondents' family type

\begin{tabular}{|l|c|c|}
\hline Categories & Frequency & Percent \\
\hline Nuclear & 175 & 58.1 \\
\hline Joint & 126 & 41.9 \\
\hline Total & $\mathbf{3 0 1}$ & $\mathbf{1 0 0 . 0}$ \\
\hline
\end{tabular}

Table 1 shows the percentage distribution of respondents' ages. Most of the respondents were between the age group 30-34 years (32.9\%). Whereas $24.3 \%$ and $22.6 \%$ of the respondents belong to age group 25-29 and 35-39 respectively. Only $1.7 \%$ and $1.0 \%$ of the respondents belong to age group 45-49 and 15-19.

Table 2 indicates the percentage distribution of respondents' years of education. Majority of the respondents (40.5\%) completed their 11-16 years of education. While $39.9 \%$ of the respondents completed their 6-10 years of education. Only $19.6 \%$ of the respondents had 0-5 years of education.

Table 3 indicates the percentage distribution of respondents' age at marriage. Majority of the respondents $46.2 \%$ and $43.9 \%$ were of age $21-26$ and $15-20$ years respectively when they got married. Only $10.0 \%$ of the respondents were in the age group $27-31$ years at the time of marriage.

Table 4 shows that majority of the respondents' (26.6\%) monthly family income was between $20001-30000$. Whereas $22.9 \%$ of the respondents' monthly family income was $10001-20000.19 .6 \%$ and $18.6 \%$ of the respondents' monthly family income was 40001 and above and $30001-40000.4 \%$ of the respondents did not know the monthly family income.

Table 5 depicts the percentage distribution of respondents' family size. Majority of the respondents $(50.5 \%)$ had family size of $4-6$ number of people. Whereas, $26.2 \%$ of the respondents had family size of 7-9 number of people. Moreover, $14.0 \%$ of the respondents had 10-12 family size and $9.3 \%$ of the respondents had family size of 1-3 number of people. 
Table 6indicates that majority of the respondents $(58.1 \%)$ had nuclear family type. Whereas, $41.9 \%$ were living in joint family system.

\section{Pearson's Correlation}

Table: 7

Pearson's correlation of self-esteem, health locus of control and awareness about safe motherhood practices

\begin{tabular}{|c|c|c|c|c|}
\hline & & $\begin{array}{c}\text { Self- } \\
\text { esteem }\end{array}$ & $\begin{array}{c}\text { Health locus } \\
\text { of control }\end{array}$ & $\begin{array}{c}\text { Awareness about } \\
\text { safemotherhood } \\
\text { practices }\end{array}$ \\
\hline \multirow[t]{3}{*}{ Self-esteem } & $\begin{array}{c}\text { Pearson } \\
\text { Correlation }\end{array}$ & 1 & $.352^{* *}$ & $.244^{* *}$ \\
\hline & Sig. (2-tailed) & & .000 & .000 \\
\hline & $\mathrm{N}$ & 301 & 301 & 301 \\
\hline \multirow[t]{3}{*}{$\begin{array}{l}\text { Health locus of } \\
\text { control }\end{array}$} & $\begin{array}{c}\text { Pearson } \\
\text { Correlation }\end{array}$ & $.352^{* *}$ & 1 & $.270^{* *}$ \\
\hline & Sig. (2-tailed) & .000 & & .000 \\
\hline & $\mathrm{N}$ & 301 & 301 & 301 \\
\hline \multirow[t]{3}{*}{$\begin{array}{l}\text { Awareness about } \\
\text { safemotherhood }\end{array}$} & $\begin{array}{c}\text { Pearson } \\
\text { Correlation }\end{array}$ & $.244^{* *}$ & $.270^{* *}$ & 1 \\
\hline & Sig. (2-tailed) & .000 & .000 & \\
\hline & $\mathrm{N}$ & 301 & 301 & 301 \\
\hline
\end{tabular}

Table 7 shows the correlation among three variables that are self-esteem, health locus of control and awareness about safe motherhood practices among the married females. The results of the correlation matrix indicated positive and significant relationship even at the p-value of 0.01 . The above table shows that self-esteem had a strong positive and highly significant correlation with both awareness about safe motherhood i.e. $0.244(0.000)$ and health locus of control i.e. $0.352(0.000)$ respectively. Similarly, health locus of control had positive and significant correlation with self-esteem $0.352(0.000)$ and awareness about safe motherhood practices $0.270(0.000)$ respectively. In the light of above stated correlation matrix, it is concluded that self-esteem and health locus of control had positive and significant correlation with awareness about health locus of control. Further, it is inferred that favorable psychological motives that are self-esteem and health locus of control increases awareness about safe motherhood practices among females. Maleki and Mazloomzadeh (2013) investigated the perceived internal control of women and its consequences for future pregnancy outcomes. It was found in the study that the women had good perceived internal control. It showed a positive and significant relationship with age and as well as with the knowledge of folic acid. 
Above study showed that good internal locus of control significantly affects awareness level of the women about their pregnancy outcomes and it ultimately affects the reproductive health.

\section{Regression Analysis}

Table: 8

Coefficient results when safe motherhood practices is dependent and self-esteem and health locus of control are independent variables

\begin{tabular}{|c|c|c|c|c|c|c|}
\hline \multirow{2}{*}{\multicolumn{2}{|c|}{ Model }} & \multicolumn{2}{|c|}{$\begin{array}{c}\text { Un-standardized } \\
\text { Coefficients }\end{array}$} & \multirow{2}{*}{$\begin{array}{c}\begin{array}{c}\text { Standardized } \\
\text { Coefficients }\end{array} \\
\text { Beta } \\
\end{array}$} & \multirow[b]{2}{*}{ t } & \multirow[b]{2}{*}{ Sig. } \\
\hline & & $\mathbf{B}$ & Std. Error & & & \\
\hline \multirow[t]{3}{*}{1} & (Constant) & 1.369 & .155 & & 8.837 & .000 \\
\hline & Self-esteem & .185 & .064 & .170 & 2.888 & .004 \\
\hline & $\begin{array}{l}\text { Health locus of } \\
\text { control }\end{array}$ & .253 & .071 & .210 & 3.568 & .000 \\
\hline
\end{tabular}

Table 8 shows the results of regression that is calculated by considering awareness about safe motherhood practices as dependent variable and self-esteem and health locus of control as independent variables. Regression coefficient showed the importance of independent variable in making regression model. The regression coefficient is denoted by $\beta$. The model explains that Self-esteem had positive influence on awareness about safe motherhood practices. The p-value of predictor is less than 0.05 which depicts that influence of self-esteem on safe motherhood practices is significant. Regression coefficient of self-esteem had depicted that if one unit change is made in independent variable, it causes 0.170 scores change in dependent variable.

Similarly, health locus of control had positive and significant influence on dependent variable. The significance of the influence was estimated by p-value that is less than 0.05regression coefficient of health locus of control had depicted that if one unit change is made in independent variable, it causes 0.210 scores change in dependent variable.

The results of the present study were also supported by the literature. Blanc and Wolff (2001) investigated the relationship between health locus of control and use of condoms in Uganda. They used a series of health locus of control questions that helped to measure the relationship between health locus of control and use of condoms. The study found the positive and significant relation of health locus of control with use of condoms and hence fertility control. Laffery and Isenberg (2003) discussed the literature regarding attitude and health of the individuals. The broad range of literature has shown the importance of internal locus of control for the positive health behavior. Internal locus of control is the person's own belief in the effectiveness of behavior. 
Most of the developed countries have taken significant progressive steps towards lowering the maternal mortality rate. It is quite pertinent to mention that increasing safe motherhood practices help in reducing pregnancy related adverse outcomes (Okereke et al, 2013).

Figure 1: Causal model to predict overall effects of self-esteem and health locus of control on awareness about safe motherhood practices

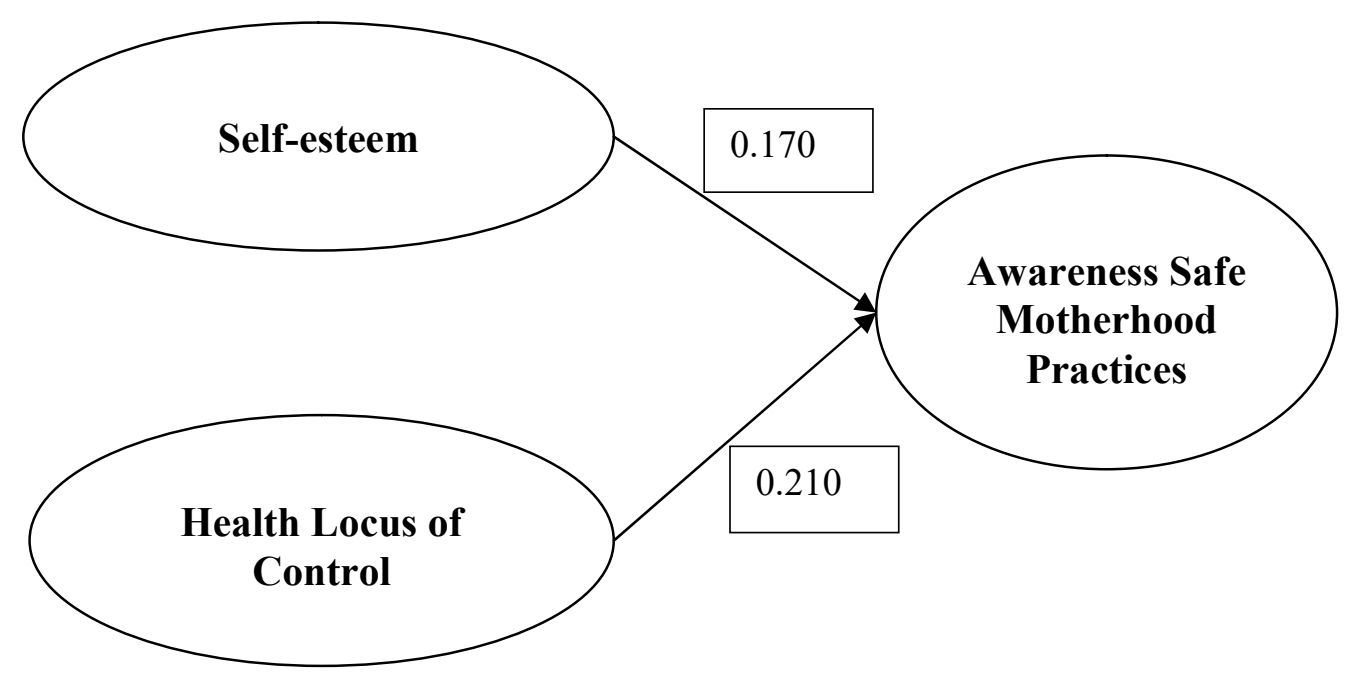

\section{Conclusions}

The present study focused to investigate the relationship between the psychological motives and awareness about safe motherhood practices among married females of Gujrat. The researchers hypothesized that there exists a significant relationship between psychological motives and awareness about safe motherhood practices among married females. It was also hypothesized that females had favorable psychological conditions that are self-esteem and health locus of control which helped them in enhancing the awareness regarding safe motherhood practices. The hypothesized relationship was proven significant as depicted by the values of Pearson's correlation matrix and regression coefficient.

In a net shell, it was concluded that females holding favorable psychological motives (self-esteem and health locus of control) had increased awareness about safe motherhood practices. 


\section{Recommendations}

Keeping in view the findings, the present study recommends that the females of more vulnerable group must also be targeted along with their partners. Enhanced psychological services must also be available for the couples. Proper planning to spread the safe motherhood practices across the region is required which is a basic stone for policy making at national level.

\section{Future Research}

Further research studies can also be conducted to investigate the role of husband, motherin law and other elder females of family on woman's reproductive health care seeking.

\section{References}

Action Health (1999). Meeting the Sexual and Reproductive Health Needs of Young People in Nigeria: A Guide for Action, Lagos.

Blanc, A.K. \& Wolff, B. (2001). Gender and Decision-Making Over Condom Use in Two Districts in Uganda. Reproductive Health, vol.5:3, p.152.

Daly, P., Azefor, M. \& Nasah, B. (1993). Safe Mother in Francophone Africa: Some Improvement but not Enough. University of Pennsylvania: African StudiesCentre.

Demographic and Health Survey (2002). Demographic issues in Pakistan, National Institute Population Studies (NIPS), Islamabad.

Gani, M. S., Chowdhury, A. M. R. \& Nyström, L. (2014). Urban-Rural and Socioeconomic Variations in the Knowledge of STIs and AIDS Among Bangladeshi Adolescents. Asia Pacific Journal of Public Health, vol.26:2, pp.182-195.

Garg, B. S., Chhabra, S. \& Zothanzami, S. M. (2006). Safe Motherhood: Social, Economic and Medical Determinants of Maternal Mortality. Women and Health Learning Package, The Network: TUFH Women and Health Taskforce. Karachi: The Network, 1132.

Islam, MZ. Shaila, H., Farzana, Z. (2011). Reproductive Health Profile of Married Women: Experience from a Rural Community of Bangladesh. Bangladesh Journal of Medical Science, vol.10:4. 
Jatau, A.A. (2000). Strategies for Promoting Safe Motherhood in Nigeria by the 2010 . Nigeria Journal of Health Education, vol.9, pp.282-294.

Jejeebhoy, S.J. (1995). Women's Education, Autonomy and Reproductive Behaviour: Experience from Developing Countries. Oxford, England: Clarendon Publications.

John-Nwosu, Q. N. (2011). Attitude of Pregnant Women Towards Safe Motherhood Initiative S In Orlu Urban Imo State.

Khan, M. M., Zafar, M. I., Ali, T. \& Ahmad, A. (2009). Effect of Socio-Economic, Cultural and Demographic Factors on Woman Reproductive Health. Pak. J. Agri. Sci, vol.46:4, pp.308-314.

Laffery, S.C \& Isenburg, M. (2003). The Relationship of Internal Locus of Control, Value Placed on Health, Perceived Importance of Exercise and Participation in Physical Activity during Leisure. International Journal of Nursing Studies, vol.40, pp.453-459.

Lee, T. R., \& Mancini, J. A. (1981). Locus of control and premarital sexual behaviors. Psychological Reports, 49(3), 882.

Maleki, A. \& Mazloomzadeh, S. (2013). Women's Perceived Internal Control of Future Pregnancy Outcomes and its Related Factors. Iranian Journal of Nursing and Midwifery Research, vol.18:2, p.158.

Mondal, M. N. I., Rahman, M. M., Rahman, M. O. \& Akter, M. N. (2012). Level of Awareness about HIV/AIDS among Ever Married Women in Bangladesh. Food and Public Health, vol.2:3, pp.73-78.

Moshki, M., Tavakolizadeh, J., \& Bahri, N. (2010). The relationship between health locus of control and life style in pregnant women. Armaghane danesh, 15(2), 161-170.

Mustafa, R., Afreen, U., \& Hashmi, H. A. (2008). Contraceptive knowledge, attitude and practice among rural women. J Coll Physicians Surg Pak, 18(9), 542-545.

Nigerian Partnership for Safe Motherhood (2003). Training Curriculum for leadership in safe motherhood initiative. University Press Ibadan. 
Jatau, A. A. (2000). Strategies for Promoting Safe Motherhood in Nigeria by the 2010. Nigeria Journal of Health Education, vol.9, pp.282-294.

Norman, P., Bennett, P., Smith, C. \& Murphy, S. (1998). Health Locus of Control and Health Behaviour. Journal of Health Psychology, vol.3:2, pp.171-180.

Okereke, E., Aradeon, S., Akerele, A., Tanko, M., Yisa, I., \& Obonyo, B. (2013). Knowledge of safe motherhood among women in rural communities in northern Nigeria: implications for maternal mortality reduction. Reproductive Health, vol.10:1, p.57.

Oladeji, D. (2014). Socio-psychological factors as determinants of reproductive health behaviour among couples in Nigeria. IFE PsychologIA: An International Journal, vol.22:1, pp.187-194.

PATHS (2005). Maternal and child health. Journal of World Health Forum, 7 (21), 11 21.

Punam, D. \& Bhawana, B. (2017). Male Participation in Safe Motherhood in Selected Village Development Committee of Morang, Nepal, 2016. Diabetes Management, vol.7:2, pp.210-217.

Ravi, R. P. \& Kulasekaran, R. A. (2014). Comprehensive Knowledge and Practices about Sexually Transmitted Infections among Young Married Rural Women in South India. American Journal of Epidemiology and Infectious Disease, vol.2:1, pp.41-46.

Shirpak, K. R., Chinichian, M., Maticka-Tyndale, E., Ardebili, H. E., Pourreza, A. \& Ramenzankhani, A. (2008). A Qualitative Assessment of the Sex Education Needs of Married Iranian Women. Sexuality \& Culture, vol.12:3, pp.133-150.

Surat, L.L. (2002). Dead Mothers and Injured Wives: The Social Context of Maternal Morbidity among Hausas of Northern Nigeria Studies on Family Planning. Journal of Family Planning, vol.29:4, pp.7-9.

Sewankambo, N., Gray, R. H., Wawer, M. J., Paxton, L., McNairn, D., Wabwire-Mangen, F. \& Rabe, L. (1997). HIV-1 Infection Associated with Abnormal Vaginal Flora Morphology and Bacterial Vaginosis. The Lancet, 350(9077), 546-550. 
226 The Psychological Motives of Safe Motherhood Practices: A Case of Married Females in Gujrat

Ugoji, F. N. (2004). Self-Concept and Locus of Control as Correlates of the Knowledge and Attitude of Students in Tertiary Institutions towards Reproductive Health. An Unpublished Ph.D Thesis Delta State University, Abraka.

Victor, E. A. \& Haruna, K. (2012). Relationship between Health Locus of Control and Sexual risk Behaviour, Retrovirology, vol.9:1, p.62.

Wasserheit J. (1992). Epidemiological Synergy: Interrelationships between Human Immune Deficiency Virus Infection and Other Sexually Transmitted Diseases, Sexually Transmitted Diseases, 19:2, 61-77.

Cohen, M. S. (1998). Sexually transmitted diseases enhance HIV transmission: no longer a hypothesis. The Lancet, 351, S5-S7.

World Bank (2004). World Development Report. The Development Indicators, New York.

Ummel Baneen is an Associate Lecturer in the Department of Population Sciences, University of Gujrat.

Prof. Dr. Fauzia Maqsood is Dean, Faculty of Social Sciences, University of Gujrat.

Sidra Maqsood is an Assistant Professor in the Government College University, Lahore. 